\title{
THE PERFORMANCE OF DAIRY CATTLE GRAZING TWO VARIETIES OF TALL FESCUE
}

\author{
G. F. WILSON \\ Dairy Husbandry Department, M assey University, \\ Palmerston N orth
}

\begin{abstract}
Two varieties of tall fescue were compared with 'Grasslands Ariki' ryegrass as feeds for lactating, and growing cattle. In three shortterm experimeats the dairy cows grazing the different types of pasture produced similar quantities of milk and in most -cases the fat and protein contents did not differ significantly. On the other hand, the exclusion of clover from the grass swards led to a lower milk production. Liveweight gains were consistently higher for yearling cattle grazing Ariki ryegrass compared with the two fescue swards. The in vifro digestibility of S170 was lower than the value for G4710 but because of the high clover content of the S170 pastures animal performance was similar.
\end{abstract}

\section{INTRODUCTION}

Tard Fescue (Festuca arundinacea Schreb.) is well adapted to many climatic and soil conditions, and within New Zealand two varieties (Aberystwyth S170 and Grasslands 4710) have produced higher dry matter yields, especially over the summer, than the widely used 'Grasslands Ariki' ryegrass (L. B. Anderson, pers. comm.). On the other hand, tall fescue in many other countries has shown undesirable characteristics. Animal performance has been reported to be inferior to that obtained when stock graze other pastures (Jacobson et al., 1970). Some fescue varieties may also contain a toxic factor which causes "fescue foot" in cattle. The condition is characterized by swelling of the feet owing to constriction of blood vessels, and in extreme cases, dry gangrene of the feet and distal portion of the tail.

Because of the outstanding attributes of the two varieties grown in New Zealand, it was considered important to assess their feeding values for use by growing and lactating cattle.

Two tall fescue varieties were compared with Ariki ryegrass in three short grazing experiments using lactating cows, and growth rates of yearling dairy cattle were measured over the winter and spring periods. 
EXPERIMENTAL

\section{P ASTURES}

Ariki ryegrass, S170 and G4710 tall fescues were sown as pure swards in fertile soil (Manawatu sandy loam) during April, together with $125 \mathrm{~kg} / \mathrm{ha}$ of superphosphate. They were subsequently maintained with sulphate of ammonia or urea $(300 \mathrm{~kg} /$ ha/yr) and superphosphate ( $125 \mathrm{~kg} / \mathrm{ha})$.

\section{AnImals AND DESIGN OF ExPERIMENTS \\ M ilk Production Experiments}

Two short experiments $(1,2)$ were carried out using 9 pairs of monozygous twins during the October to December period, and a further experiment (3) using 12 pairs of twins during November.

The majority of the twins were Jersey or Jersey $x$ Friesian cross animals which had calved during July and August and they were allocated to treatments in accordance with a balanced incomplete block design (Cochran and Cox, 1950). The duration of all experimental periods was 10 to 14 days (see Table 3) and all cows were given sufficient pasture to ensure full feeding. All animals used in an experiment were grazed as a single group on mixed grass/clover swards both before and after the experimental periods.

In an additional study, day-to-day variations in mean herd yield were recorded over a three-month period, during which pure fescue (G4710 and S170), Ariki ryegrass and some mixed grass/clover pastures: were grazed in a random order.

\section{Growth-rate Studies}

The liveweight gains of monozygous twin heifers grazing the fescue and Aniki ryegrass swards were recorded in three experiments. Three pairs of twins were used in Experiment 4 in which G4710 and Ariki ryegrass swards were compared. In Experiments 5 and 6 , nine pairs of twins were allocated to the three treatments in a balanced incomplete block design, and in addition three unrelated animals were used on each treatment in Experiment 5 .

The animals were mainly Jersey or Jersey $X$ Friesian cross and weighed between 120 and $150 \mathrm{~kg}$ at the commencement $\mathrm{cf}$ th: experiments, 
Experiments 4 and 5 were undertaken using immature and mature pastures, respectively, during the winter period. For Experiment 6 , short immature pasture was grazed during the spring period.

In all cases the stocking rate and the duration of the experiments were adjusted to ensure that voluntary intakes were not restricted.

\section{SAMPLiNg AND ANALYTical Methods}

\section{Herbage}

Samples were obtained at fortnightly intervals and on most occasions the botanical composition of the swards was also determined. All samples were freeze-dried, grouad to pass a $1 \mathrm{~mm}$ sieve, and stored in airtight containers at room temperature prior to analysis for crude protein, and acid detergent fibre (Van Soest, 1963). Organic matter digestibilities were also obtained in two of the experiments using the in vitro method of Tilley and Terry (1963).

\section{M ilk}

Milk yields were measured at all milkings between Sunday p.m. and Friday a.m. of each week during the preliminary (2 week) and experimental periods. Fat, protein and lactose percentages were measured by infra-red milk andyser using daily composites for individual cows.

The milk yield end composition data were analysed by covariance analysis. Tests of significance were made between the adjusted treatment means using the values obtained during the preliminary period as the independent variables.

\section{Liveweight Gains}

The liveweights of animals were recorded once each week during the experimental period but on two consecutive days at the commencement of each experiment. The animals were also weighed for a period of several weeks after the conclusion of the experimental periods in order to measure the extent of differences in "gut fill" between treatments. Because these differences were very important, the apparent growth rates over the experimental periods were adjusted to eliminate this effect. The adjusted growth rates for individuall animals were analysed by analysis of variance. 
RESULTS

PASTURES

Difficulty was encountered in establishing a relatively pure sward of S170 fescue owing to slow establishment of the seedlings. Hence contamination with "other grasses" (mainly Poa species) and clover in this sward was considerably greater than for the other two swards (see Table 1).

TABLE 1: MEAN BOTANICAL ANALYSIS OF PASTURES DURING EXPERIMENTAL PERIODS $(\%)$

\begin{tabular}{|c|c|c|c|c|c|c|c|c|c|}
\hline \multirow[b]{3}{*}{ Experiment } & \multicolumn{3}{|c|}{ G4710 } & \multicolumn{3}{|c|}{$\$ 170$} & \multicolumn{3}{|c|}{ Ariki } \\
\hline & \multicolumn{3}{|c|}{ Other } & \multicolumn{3}{|c|}{ Other } & \multicolumn{3}{|c|}{ Other } \\
\hline & G4710 & Grass & Clover & S170 & Grass & Clover & Ariki & Grass & Clover \\
\hline 1 & 89 & 5 & 6 & 66 & 16 & 18 & 81 & 10 & 9 \\
\hline 2 & 72 & 14 & 14 & 53 & 12 & 35 & 73 & 11 & 16 \\
\hline 3 & 84 & 16 & 10 & 62 & 20 & 18 & 71 & 14 & 15 \\
\hline 4 & 92 & 5 & 3 & & - & & 84 & 11 & 5 \\
\hline 5 & 95 & 4 & 1 & 75 & 19 & 6 & 88 & 8 & 4 \\
\hline 6 & 90 & 6 & 4 & 72 & 16 & 12 & 80 & 12 & 8 \\
\hline
\end{tabular}

TABLE 2: MEAN CRUDE PROTEIN CONTENT, ACID DETERGENT FIBRE CONTENT AND ORGANIC MATTER DIGESTIBILITY OF ARIKI AND TALL FESCUE PASTURES (\%)

\begin{tabular}{lcccccc}
\hline Experiment $:$ & 1 & 2 & 3 & 4 & 5 & 6 \\
Mean date: & Oct. & Dec. & Nbv. & Jul. & Jun. & Sep. \\
\hline Crude protein: & & & & & & \\
$\quad$ G 4710 & 18.1 & 15.8 & 19.4 & 25.6 & 21.7 & 30.1 \\
S170 & 20.1 & 19.7 & 20.0 & $\mathbf{-}$ & 21.3 & 30.6 \\
$\quad$ Ariki & 18.4 & 15.0 & 20.4 & 27.0 & 22.9 & 25.7 \\
Acid detergent & fibre: & & & & & \\
$\quad$ G4710 & 25.4 & 29.2 & 28.6 & 19.2 & 23.0 & 18.8 \\
S170 & 24.4 & 23.7 & 30.4 & $\mathbf{-}$ & 25.0 & 19.4 \\
$\quad$ Ariki & 23.0 & 29.5 & 27.8 & $\mathbf{1 7 . 9}$ & 21.0 & 20.2 \\
DM digestibility: & & & & & & \\
G4710 & 63.1 & $\mathbf{-}$ & $\mathbf{-}$ & $\mathbf{-}$ & $\mathbf{-}$ & 82.0 \\
$\quad$ S170 & 59.5 & $\mathbf{-}$ & $\mathbf{-}$ & $\mathbf{-}$ & $\mathbf{-}$ & 87.0 \\
$\quad$ Ariki & 68.5 & $\mathbf{-}$ & $\mathbf{-}$ & $\mathbf{-}$ & $\mathbf{-}$ \\
\hline
\end{tabular}

Protein and acid detergent fibre values (Table 2) varied with the season, and to some extent as a result of the varying clover content of the swards, but differences between grasses were small. The organic matter digestibility for the S170 pasture was consistently lower than the values for the other two grasses. 
Milk Yield AND Composition

The adjusted mean data for milk yield and composition are given in Table 3 , and very few of the differences between pasture varieties reached significance at the $5 \%$ level. The major exceptioa to this was that the cows grazing $\mathrm{S} 170$ in Experiment 2 produced higher milk and fat yields than the cows grazing G4710. However, the clover content of the S170 pastures was abnormally high $(35 \%)$ during this experiment.

TABLE 3: THE EFFECT OF TWO VARIETIES OF FESCUE AND ARIKI RYEGRASS ON MILK YIELD AND COMPOSITION : ADJUSTED MEAN VALUES FOR EXPERIMENTAL PERIOD

\begin{tabular}{|c|c|c|c|c|c|}
\hline & $\begin{array}{l}\text { Fescue } \\
\text { G4710 }\end{array}$ & $\begin{array}{c}\text { Fescue } \\
\text { S170 }\end{array}$ & Ariki & $\stackrel{S i g n}{\mathrm{P}}$ & $\begin{array}{l}\text { iif. Diff } \\
<0.05\end{array}$ \\
\hline \multicolumn{6}{|c|}{ Experiment 1 (22.10.71-2.11.71): } \\
\hline Milk (kg/cow/day) & 12.45 & 12.46 & 13.32 & & - \\
\hline Fat $\%$ & 4.60 & 4.93 & 4.92 & & - \\
\hline Fat (kg/cow/day) & 0.57 & 0.62 & 0.66 & & - \\
\hline Protein \% & 3.46 & 3.52 & 3.60 & 4710 & $<\mathrm{A}$ \\
\hline Lactose \% & 5.12 & 5.05 & 4.99 & & - \\
\hline \multicolumn{6}{|c|}{ Experiment 2 (24.11.71-3.12.71): } \\
\hline Milk (kg/cow/day) & 11.00 & 12.02 & 11.58 & 4710 & $<\mathrm{S} 170$ \\
\hline Fat $\%$ & 4.87 & 4.95 & 4.84 & & $\longrightarrow$ \\
\hline Fat (kg/cow/day! & 0.53 & 0.59 & 0.56 & 4710 & $<5170$ \\
\hline Protein \% & 3.57 & 3.63 & 3.71 & 4710 & $<\mathrm{A}$ \\
\hline Lactose \% & 5.08 & 5.08 & 5.10 & & \\
\hline \multicolumn{6}{|c|}{ Experiment $3(30.10 .72-17.11 .72):$} \\
\hline Milk (kg/cow/day) & 10.56 & 10.75 & 11.02 & & - \\
\hline Fat $\%$ & 5.27 & 5.31 & 5.19 & & - \\
\hline Fat (kg/cow/day) & 0.57 & 0.57 & 0.57 & & $\rightarrow$ \\
\hline Protein \% & 3.69 & 3.71 & 3.69 & & - \\
\hline Lactose $\%$ & 5.02 & 5.02 & 4.99 & & $=$ \\
\hline
\end{tabular}

The mean milk yields of the whole herd grazing irrigated grass/ clover swards, and "clover free" Ariki ryegrass and fescue swards during the summer period are shown in Fig. 1. The importance of including clover in a sward was clearly demonstrated, the regression line relating milk yield to time being significantly higher $(\mathrm{P}<0.05)$ for the swards containing clover.

\section{IVEWEIght GAIN}

The mean growth rates of the yearling heifers grazing the Ariki ryegrass and the fescue pastures during the winter period in Experiment 5 are shown in Fig. 2. While the apparent growth rates 


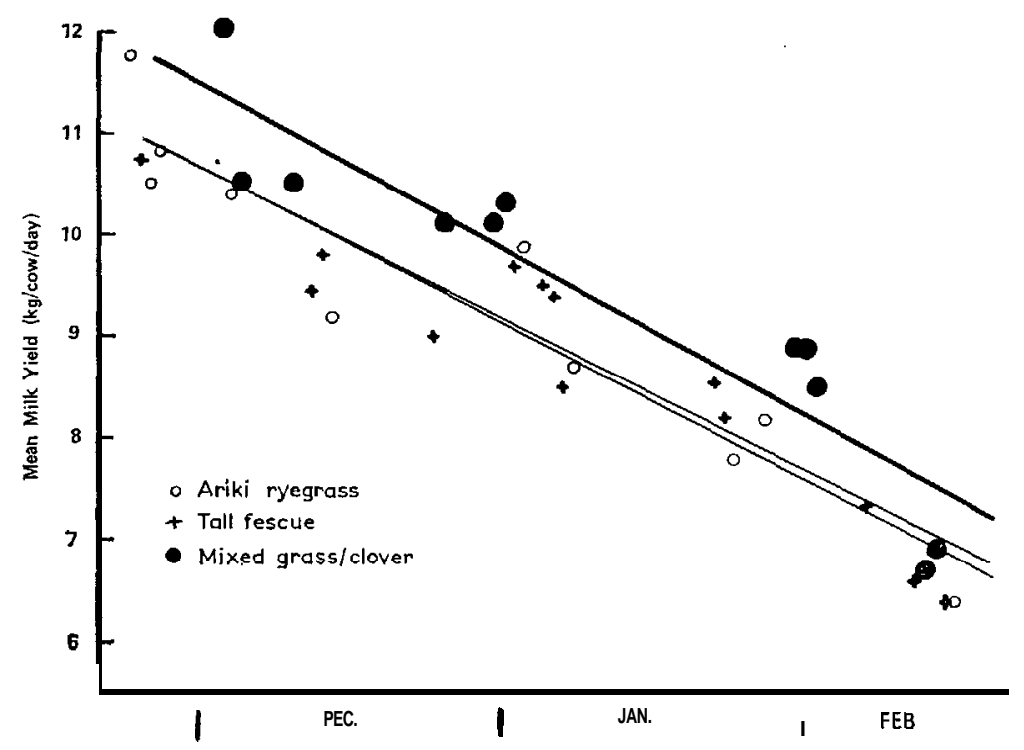

Fig. 1: Meun daily milk yields of cows grazing mixed grass/clover swards and pure swards of Ariki ryegrass and tall fescue.

appeared fairly similar for the three groups during the experimental period, the differences between the treatments (particularly Ariki and S170) increased when the animals were grazed together on normal mixed pasture at the conclusion of the experiment.

It is therefore likely that the animals grazing the fescue pastures actually grew more slowly than those in the Ariki ryegrass group and the apparently similar gains during the experimental period were confounded by a larger "gut fill" in the case of the animals fed $\mathbf{S 1 7 0 . T h e}$ mean growth rates in the three experiments after being corrected for "gut fill" differences are presented in Table 4. Although none of the differences between treatments quite reached significance $(5 \%)$, growth rates of the animals on the fescue pastures were consistently lower than those grazing Ariki ryegrass. Liveweight gains were also depressed by the long pastures used in Experiment 5 compared with the gains made in other experiments.

None of the animals in any of the experiments showed any signs of lameness or cither indications of fescue foot. On the other hand, several animals among a small group of yearling cattle grazing some "unimproved" tall fescue on an adjacent area did 


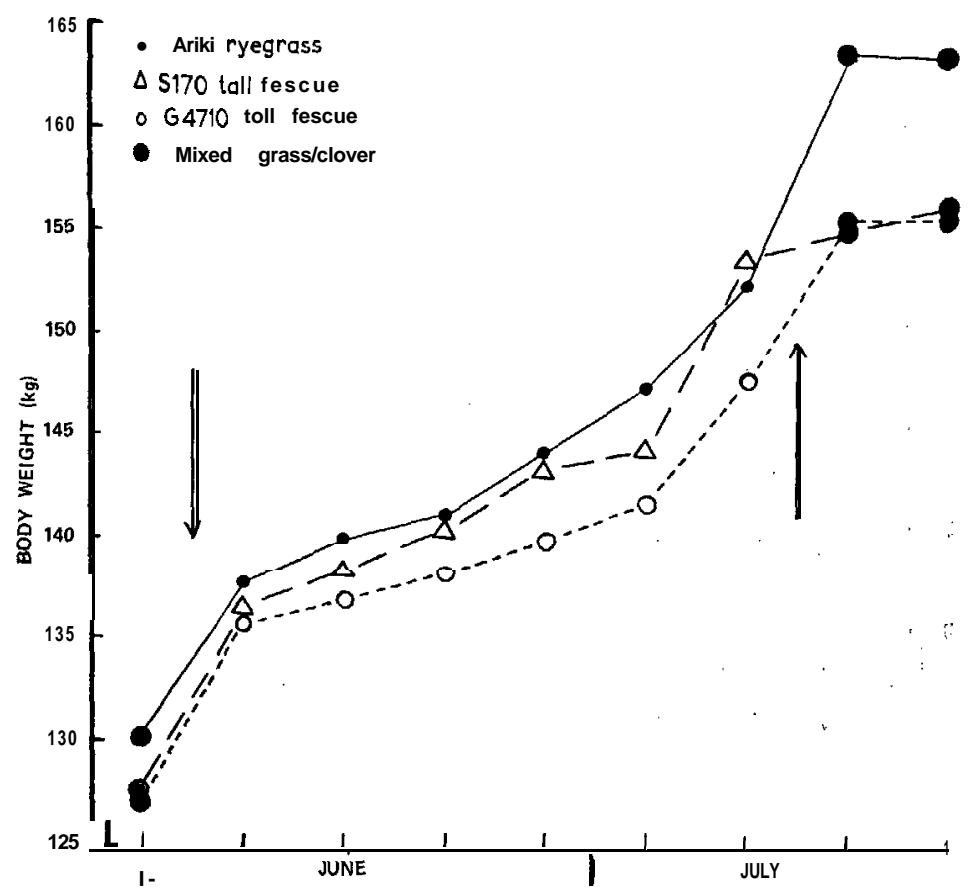

FIG. 2: Liveweight gains of heifers grazing Ariki ryegrass, $S 170$ tall fescue, and G4710 tall fescue. All animals grazed mixed grass/clover swards during pre-experimental and post-experimental periods.

suffer from fescue foot a fortnight before the commencement of Experiment 4.

\section{DISCUSSION}

The two aspects which warrant discussion are the comparisons between the tall fescues and Ariki ryegrass, and the relative merits of the two varieties of fescue.

Differences between treatments, in term's of milk yield and composition, were very small, and statistically non-significant in all cases except in Experiment 3 when the higher production from S170 could be accounted for by the fact that the pasture contained an abnormally large proportion of clover. The beneficial effects of the inclusion of clover in a grass sward on milk nroduction was clearly demonstrated in the herd data presented in Fig. 1. 
TABLE 4: THE EFFECT OF TWO VARIETIES OF FESCUE AND ARIKI RYEGRASS ON THE GROWTH RATES OF YEARLING HEIFERS

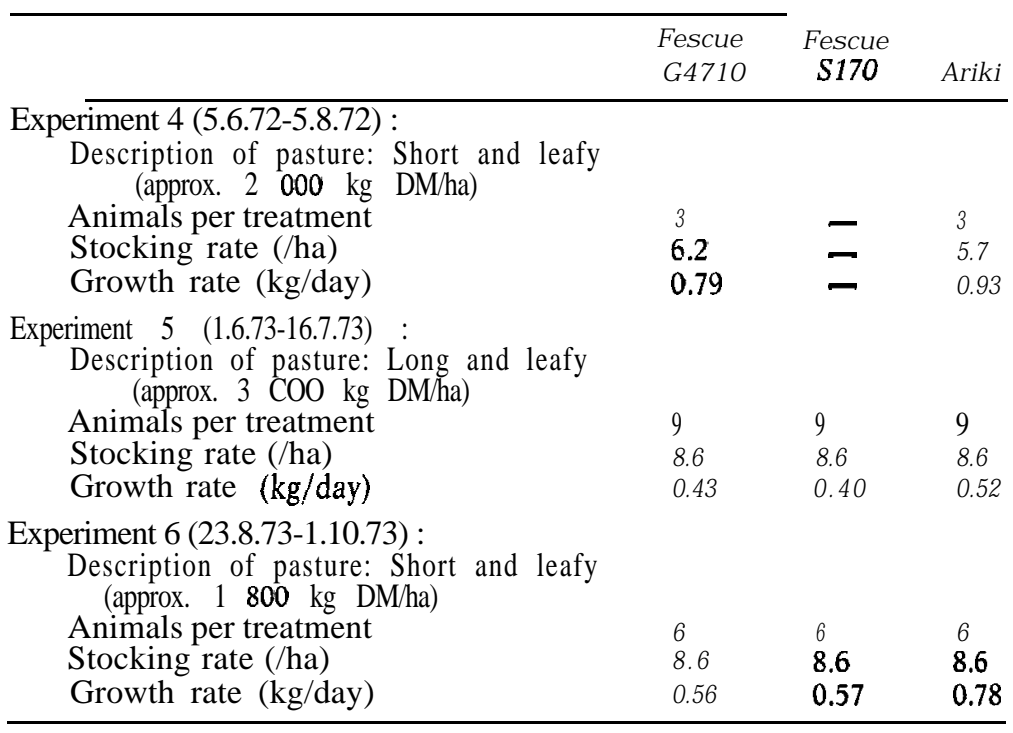

The liveweight gains achieved by the yearling cattle grazing the fescue swards were consistently lower (approximately 20\%) than those grazing the Ariki ryegrass. The results are therefore in agreement with previous results carried out in other countries which indicate that the nutritive value of tall fescues can be low (Minson et al., 1964; Jacobson et al., 1970). The reason for low nutritive value is not apparent from the chemical analyses undertaken, but the greater "gut fill" of the animals grazing the fescues, and especially S170, suggests that the rate of breakdown of cell wall material in the rumen is considerably slower. A limited number of in vitro digestibility analyses confirmed that the digestibility of S170 was lower than for G4710 and Ariki ryegrass. In this connection it is also of interest that Bush et al. (1970) reported that the alkaloid, perloline, which may occur in high concentratioas in fescue, depressed the in vitro digestibility of cellulose. While only limited evidence was obtained to suggest that there is a significant difference in nutritive value between the two varieties of fescue, the agronomic factors such as the quicker establishment of G4710 compared with S170 may be of importance in practice. 
Clovers and possibly other grasses would normally be sown along with tall fescue so that animal performance would be ex pected to be better than that achieved in the current experiments. However, the need to maintain adequate controll of tall fescue plants by regular grazing is emphasized by the fact that variation in animal growth rates amoag experiments was greater than that among grasses within experiments. When assessing the potential of tall fescues for use in New Zealaad agriculture, the lower nutritive value may be more than offset by the much higher dry matter yield. Clearly, it is important that farmers and researchers find ways of managing pastures containing tall fescue so as to capitalize fully on its agronomic attributes.

\section{ACKNOWLEDGEMENTS}

Professor R. E. Munfosd for assistance with the milk analyses and J. A. Raven and staff of the Identical Twin Dairy Unit for field assistance. G4710 tall fescue was supplied by Grasslands Division, DSIR, Palmerston North.

\section{REFERENCES}

Bush, L. P.; Streeter, C.; Buckner, R. C., 1970: Crop Sci., 10: 108. Cochran, W. G.; Cox, G. M., 1950: Experimental Designs. Wiley, New York.

Jacobson, D. R.; Carr, S. B.; Hatton, R. H.; Buckner, R. C.; Graden, A. P.; Dowden, D. R.; Miller, W. M., 1970: J. Dairy Sci., 53: 575.

Minson, D. J.; ; Harris, C. E.; Raymond, W. F.; Nilford, R., 1964: J. Br. G rassld Soc., 19: 298.

Tilley, J. M. A.; Terry, R. A., 1963: J. Br. Grassld Soc., 18: 104.

Van Soest, P. J., 1963: J. Ass. O ff. A gric. Chem., 46: 829. 